\title{
太陽光発電・燃料電池ハイブリッドシステムの特性 （負荷形状率による影響）
}

\author{
非会員 関 口 直 俊 (東京理科大) \\ 非会員 藤 木 靖 之 (東京理科大) \\ 正員谷辰 夫 (東京理科大)
}

\section{Characteristics of Photovoltaic/Fuel Cell power Hybrid System (Effect on Electrical Load Form Factors)}

Naotoshi Sekiguchi, Non-member, Yasuyuki Fujiki, Non-member, Tatsuo Tani, Member (Science University of Tokyo)

The photovoltaic power system has a great future as clean energy instead of fossil fuel which has many environmental problems such as exhausted gas or air pollution. Sunlight, a source of energy for the system, is greatly influenced by the weather conditions, seasons and times of a day, therefore it can not supply constant electric power.

The photovoltaic/fuel cell power hybrid system is assumed, it combines PV array, hydrogen generator, storage tank and fuel cells by using hydrogen. This system can supply constant electric power to the electric load in a solitary island separated from a commercial electric network.

The possibility of this system is examined by the computer simulation. Input data includes the global irradiance on inclined plane and temperature of HASP data of Tokyo, ten kinds of electrical load forms with $400 \mathrm{MWh}$ electric power a year and conversion efficiencies of each subsystem.

As a result of simulation, it was revealed that the area of PV array with $8170 \mathrm{~m}^{2}$ and the volume of hydrogen tank from $22 \times 10^{3}$ to $30 \times 10^{3} \mathrm{k} l$ are necessary.

キーワード：太陽光発電・燃料電池ハイブリッドシステム, 負荷形状率, 水素貯蔵タンク容量, 水素発生機

\section{1.はじめに}

近い将来, 太陽光発電システムは, 太陽エネルギーをエ ネルギー源としたクリーンな発電方式として実用化が期待 されている。しかし，太陽エネルギーが気象条件, 季節, 時刻などにより変動するため, このシステムの出力は必ず しも負荷に整合せず何らかの貯蔵機能を必要とする。

著者らは, 太陽光発電システムと水素を燃料とする燃料 電池を組み合わせて, 負荷の需要に整合させ電力を安定的 に供給する太陽光発電・燃料電池ハイブリッドシステムを 提案し，その可能性について検討した(1)。このシステムは 昼間に太陽光発電システムで発生した電力を直接負荷に供 給する。また，余剩電力を利用して水素を発生させて貯蔵 し, 太陽光発電システムで十分な電力供給が困難なときに は，その水素を用いて燃料電池を介して電力が供給でき る。周知のように燃料電池システムもクリーンな小形分散
形電源として有望視されている電源であり，最近，燃料電 池の然料である水素を太陽エネルギーを使って製造しよう とする広大な計画, 研究が進められている(2)(3)。

本論文は, 10 種類の集合住宅を関東地方に設置したと 想定し，太陽光発電・燃料電池ハイブリッドシステムによ って, 負荷に電力を供給した際のシステムの年間水素貯蔵 量が最小となる太陽電池アレイ面積, 負荷パターンの変化 による年間水素貯蔵量の変化，システムの稼働状況を，シ ミュレーションにより明らかにしている。ここで用いた負 荷は, 10 種類の個人住宅用負荷パターン（年間負荷電力 量 4,000 kWh) をベースにし，同一負荷パターンが 100 軒 $(400 \mathrm{MWh} /$ 年, 平均電力 $45.7 \mathrm{~kW})$ 集まったものとした。 また，本システムと類似なシステムとして蓄電池を有する 太陽光発電システムがあるが, 両システムの年間のエネル ギーバランスについても, シミュレーションにより考察 し，この面からの本システムの有効性をも論述している。 


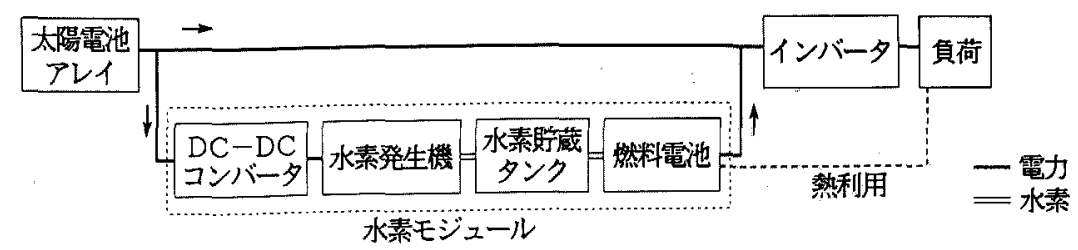

図 1 システム構成図

Fig. 1. System configuration.

\section{2. システム条件}

〈2・1〉 システム構成 本論文で検討したシステムの 構成図を図 1 に示す。システムは, 太陽電池アレイ, イン バータ, 水素モジュールから構成されている。水素モジュ ールとは, DC-DCコンバー夕, 水素発生機, 水素貯蔵夕 ンク，燃料電池をまとめたものである。

このシステムでは, 昼間太陽電池アレイで発生した電力 は, 負荷に供給されると同時に余剰電力を使用して, 水素 発生機で水素を発生させ貯蔵する。夕方から夜間にかけて あらかじめ貯蔵してある水素を燃料電池に送り，燃料電池 を介して責荷に電力を安定的に供給するシステムである。 このシステムは系統から電力供給を受ける必要がないた め, 独立電源として利用できる。また，燃料電池は発電と 同時に熱エネルギーを発生するため, 熱エネルギーを有効 利用することにより，システム効率の向上が期待できる。

〈2・2〉環境データ 太陽電池アレイの入力データと して使用する傾斜面全天日射強度と外気温度は年平均気象 データ (HASP) 東京を用いた。本論文での傾斜面全天 日射強度 $\Phi(i)\left(\mathrm{kW} / \mathrm{m}^{2}\right)$ の計算は次式によった $\Phi(i)=\Phi_{d}(i) \cos \delta \cos t+\Phi_{g}(i)(1+\cos L) / 2$

ここで， $\Phi_{d}(i)$ : 法線面直達日射強度 $\left(\mathrm{kW} / \mathrm{m}^{2}\right)$, $\Phi_{g}(i)$ : 水平面天空日射強度 $\left(\mathrm{kW} / \mathrm{m}^{2}\right), \delta$ :太陽 赤緯 $\left({ }^{\circ}\right), t$ : 時角 $\left(^{\circ}\right), L: 太$ 陽電池アレイ設

置角度 $\left(^{\circ}\right)$

(1)式で求めたデータを 1 時間ごとに時系列的に整理 し，年間（8,760 個）の傾斜面全天日射強度データとした。 また，このデータに対応して外気温度も用いた。

〈2・3〉太陽電池アレイ 本論文で使用した太陽電池 は多結晶シリコン太陽電池でありこのシミュレーション の太陽電池アレイの出力は次のように求めた。すなわち, 本学校舎屋上にて測定中の多結晶シリコン太陽電池モジュ ール（地上約 $40 \mathrm{~m}$, 傾斜角 $35.5^{\circ}$, 南向きに設直) の傾 斜面全天日射強度に対する効率，七ル温度のデータの関係 を求め, この関係と先の HASP データを用いて太陽電池 アレイの出力を算出している。ここで用いた測定データ は, 1992 年 3 月〜 1993 年 2 月の 1 年間のデータである。 これらのデータを春期 ( 3 月〜 5 月), 夏期 ( 6 月〜 8 月), 秋期 ( 9 月〜 11月), 冬期(12月〜 2月)に分け近似式を求めた。 図 2 (a) は傾斜面全天日射強度に対する多結晶シリコン

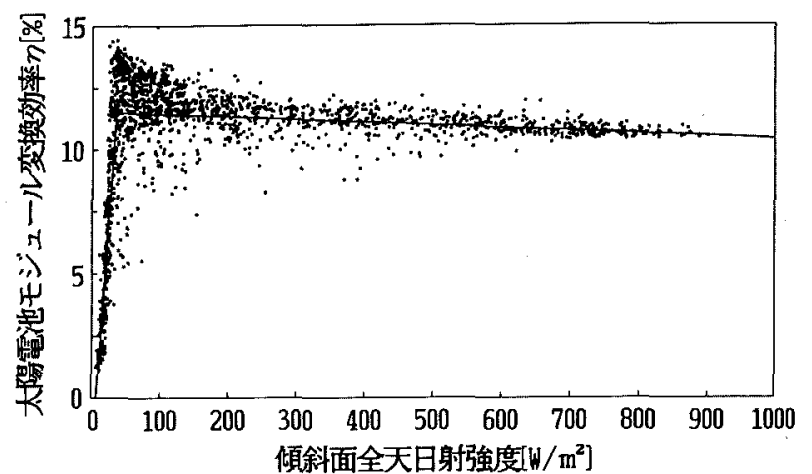

(a) 傾斜面全天日射強度に対する太陽電池モジュール㚆換効 率 $\eta$ の開係

(a) Relationship between global irradiance on inclined plane and $\eta$.

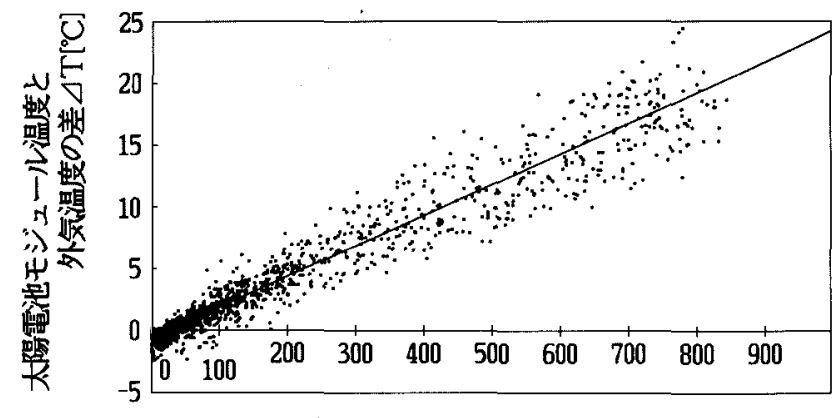

傾斜面全天日射強度 $\left[\mathrm{W} / \mathrm{m}^{2}\right]$

（b）傾斜面全天日射強度に対する太陽電池モジュール温度と 外気温度の差 $\Delta T$ の関係

(b) Relationship between global irradiance on inclined plane and $\Delta T$

図 2

Fig. 2.

太陽電池モジュール変換効率の関係の一例である。図の横 軸は傾斜面全天日射強度 $\left(\mathrm{W} / \mathrm{m}^{2}\right)$ であり，縦軸はモジュー ル温度を $25^{\circ} \mathrm{C}$ に換算したときの変換効率（\%)である。 図の特性は秋期（ 9 月〜 11月）のものである。同図より, 傾斜面全天日射強度に対する太陽電池モジュールの変換効

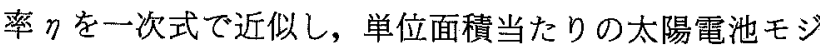
ュールの出力を $P\left(\mathrm{~kW} / \mathrm{m}^{2}\right)$ とする。いま，1月 1 日午前 0 時から $i$ 時間後の傾斜面全天日射強度を $\Phi(i)$ とする と，これらの值には次式の関係が成立する。

$$
\left.\begin{array}{l}
\eta(i)=a \Phi(i)+b \\
P(i)=\Phi(i) \eta(i)
\end{array}\right\} \ldots . . .
$$

一方，(b)図は，傾斜面全天日射強度に対する太陽電池 
表 $1 a, b, c, d$ の值

Table 1. Values of $a, b, c, d$.

\begin{tabular}{|c|c|c|c|c|c|}
\hline 期間 & $\Phi(\mathrm{i})\left[\mathrm{W} / \mathrm{m}^{2}\right]$ & a & b & c & d \\
\hline 春期 & $7.5 \sim 37.1$ & 0.37 & -2.77 & \multirow{2}{*}{0.020} & \multirow{2}{*}{-0.415} \\
\hline (3〜5月) & $37.1 \sim 1000$ & -0.001 & 10.93 & & \\
\hline 夏期 & $6.5 \sim 36.9$ & 0.37 & -2.43 & \multirow{2}{*}{0.023} & \multirow[b]{2}{*}{-0.468} \\
\hline (6〜8月) & $36.9 \sim 1000$ & -0.001 & 11.45 & & \\
\hline 秋期 & $6.6 \sim 35.0$ & 0.41 & -2.67 & \multirow[b]{2}{*}{0.024} & \multirow[b]{2}{*}{-0.588} \\
\hline (9 11月) & $35.0-1000$ & -0.001 & 11.57 & & \\
\hline 冬期 & $6.6 \sim 35.8$ & 0.37 & -2.48 & \multirow{2}{*}{0.025} & \multirow{2}{*}{-1.146} \\
\hline (12 2月) & $35.8 \sim 1000$ & -0.001 & 10.96 & & \\
\hline
\end{tabular}

モジュール温度と外気温度の差 $\Delta T$ の関係である。図の 横軸傾斜面全天日射強度であり，図の縦軸は $\Delta T$ であ る。図の特性は（a)図と同様，秋期（9月～11月）のも のであり, $i$ 時間後の $\Phi(i)$ と $\Delta T(i)$ の間の関係は次式と なる。

$$
\begin{aligned}
& \Delta T(i)=c \Phi(i)+d \\
& \text { ここで, } c, d: \text { 定数 }
\end{aligned}
$$

各期間ごとの $a, b, c, d$ の值をまとめて表 1 に示 $す^{(5)}$ 。

太陽電池アレイの年間の出力量 $P_{T}$ はアレイ面積を $S\left(\mathrm{~m}^{2}\right)$ とすると (1)〜(3)式より次式で求めることができ る。

$$
\begin{aligned}
& P_{T}=S \sum_{i=1}^{8760} P(i)\{1-0.005(t+\Delta T(i)-25)\} \cdots \cdots( \\
& \text { ここで, } t: \text { 外気温度 }\left({ }^{\circ} \mathrm{C}\right), 0.005: \text { 多結晶シリ } \\
& \text { コン太陽電池モジュールの温度係数 }{ }^{(6)}
\end{aligned}
$$

〈2・4〉 DC-DC コンバータとインバータＤC-DCコ ンバータは太陽電池アレイの発生電力を制御する機能を有 し, 特に太陽電池アレイの出力電圧を水素発生機の所定の 入力電圧に調整する働きがある。変換効率は負荷の状態に 無関係で $96.0 \%$ 一定とした ${ }^{(7)(8)}$ 。また，インバー夕は太陽 電池アレイや燃料電池からの直流電力を交流電力に変換す るもので, 変換効率は負荷の状態に無関係で $96.0 \%$ 一定 とした(7)。

〈2.5〉 水素発生機 水素発生機として固体高份子電 解質水電解方式を想定した。この方式は電極触体とイオン 交換膜とを一体化した膜-電極接合体を用い，イオン交換 膜は電解質と隔膜の両役割を果たしている。その特徵は, 電解触媒が固体電解質に接合されているため, 電解液が不 要で水を供給するのみでよい。電極間距離が膜厚のみで, 発生ガスも電極触媒の背面から発生するため, 高い電流密 度が取り出せる。純度の高い水素を得ることができる。装 置の高圧化，コンパクト化は可能であるなどがある。現 在, この水素発生機は小型機 $\left(20 \sim 30 \mathrm{Nm}^{3} / \mathrm{h}\right)$ に限られ ているが, 将来技術開発が進み大型化の要請があれば，十 分対応が可能とした。

水の電気分解に扔いては, 陰極, 陽極でそれぞれ反応が

\begin{tabular}{|c|c|}
\hline 構成要素 & 効率[\%] \\
\hline 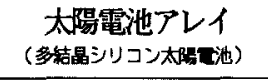 & 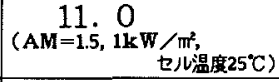 \\
\hline DC-DCコンバータ & 96.0 \\
\hline 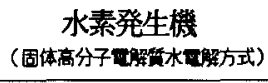 & 90.0 \\
\hline 水素貯藏夕ンク & 96. 0 \\
\hline 燃料電池 & $\begin{array}{l}\text { 40. } 0 \text { (電力) } \\
40.0 \text { (熱) }\end{array}$ \\
\hline インバータ & 96.0 \\
\hline
\end{tabular}
起こり，1 $\mathrm{mol}$ の水素を発生するのに要するエネルギーは 電子数 $2 e^{-}$であるため, 電気量 $2 \mathrm{~F}$ を要する。従って,
表 2 構成要素の変換効率

Table 2. Conversion efficiency of subsystems.

ファラデーの法則から水素の理論分解電圧以上の電圧が掛 かっているとき，このエネルギーは，69.7 Wh となる。

本論文では, 固体高分子電解質膜を用いた水素発生機の 変換効率を $90 \%$ とした ${ }^{(8)}$ 。

〈2・6〉 水素貯蔵タンク 水素発生機で発生した水素 を貯蔵するタンクである。ここで貯蔵されている水素は, 標準状態 $\left(0^{\circ} \mathrm{C}, 1 \mathrm{~atm}\right)$ で, 燃料電池の燃料として供給 される。ここでは, 水素貯蔵タンクへの水素充填に必要な エネルギーなどを考慮して, 水素貯蔵効率を $96.0 \%$ と仮 定した。

〈2・7〉 燃料電池 燃料電池は水素と酸素の化学反応 により電気エネルギーを得る直接発電変換のシステムであ る。燃料電池として実用化が最も早いと考えられているリ ン酸塩型燃料電池を想定した。この燃料電池の発電効率は $40.0 \%, 180^{\circ} \mathrm{C}$ 程度の排熱エネルギーの排熱回収効率は 40.0\%であるとした。

以上述べたシステムを構成する各要素機器の変換効率を 表 2 に示す。

\section{3. 負荷条件}

負荷として，モデル化された 10 種類の個人住宅用負荷 パターンを用いた ${ }^{(9)}$ 。住宅用負荷の 1 軒当たりの年間負荷 電力量の平均值は $4,000 \mathrm{kWh}$ である。各負荷電力量を規 格化して，ここでは，この值の住宅 100 軒 (年間負荷電力 量 $400 \mathrm{MWh}$, 平均電力 $45.7 \mathrm{~kW})$ 分を想定した。また, 負荷パターンは, 春期 ( 3 月〜 5 月), 夏期 $(6$ 月〜 8 月), 秋期 ( 9 月 11月), 冬期 (12月〜 2 月) の 4 種類 とし，各期間ではいずれも同一パターンとした。図 $3(\mathrm{a})$ に日負荷パターン(四季別平均值)を示す。

10 種類の負荷パターンの負荷形状率は 10～31\%であり, (b) 図に負荷形状率の一例を示す。ここで，負荷形状率と は, 年間の負荷電力量に対する平均負荷レベル以上の負荷 電力量の割合である(10)。すなわち，図より負荷形状率は ( $a c d$ に囲まれた面積) /(0ab8760に囲まれた面積) で表 されている。ここで用いた 10 種類の負荷パターンを表 3 に示す。10種類の負荷形状率は，10〜 $16 \%$ が 7 種類, 


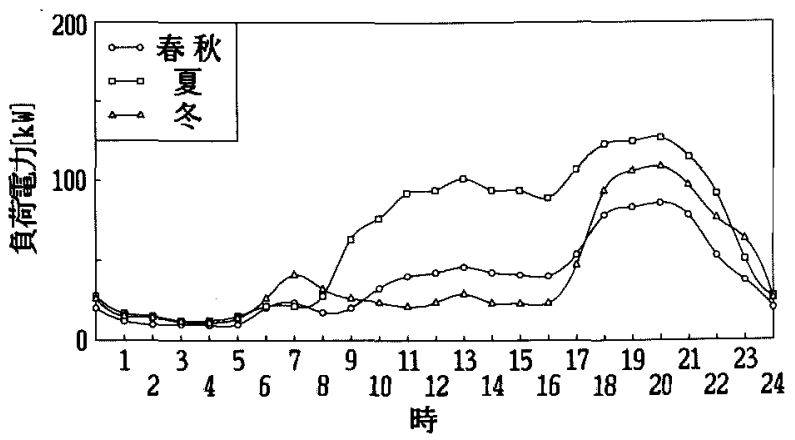

（a）日負荷パターン（四季別平均值）

(a) Daily electrical load pattern (average values of each season).

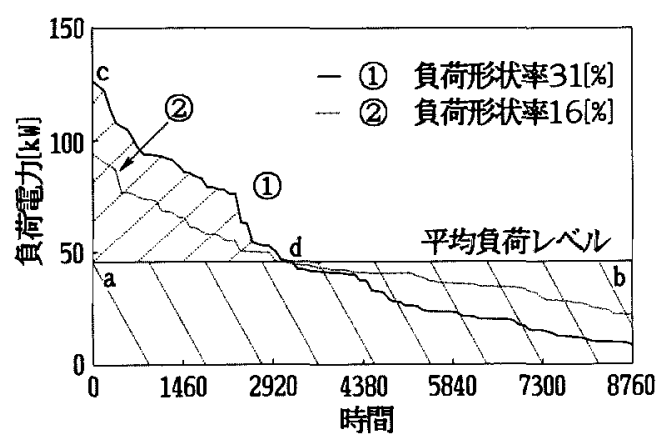

（b）負荷形状率

(b) Electrical load form factor.

図 3

Fig. 3.

表 3 負荷パターンの概要

Table 3. Summary of electrical load pattern.

\begin{tabular}{|c|c|}
\hline \multicolumn{2}{|c|}{ 負荷パターン数 : 10} \\
\hline \multicolumn{2}{|c|}{\begin{tabular}{c|} 
年間負荷電力量 : $400 \mathrm{MWh}$ \\
(4000kWh/年 $\cdot$ 軒 $\times 100$ 軒) \\
平均電力 : $45.7 \mathrm{~kW}$
\end{tabular}} \\
\hline 負荷形状率[\%] & パターン数 \\
\hline $10 \sim 16$ & 7 \\
\hline $25 \sim 31$ & 3 \\
\hline
\end{tabular}

$25 \sim 31 \%$ が 3 種類である。

\section{4. 計算手順}

シミュレーションの流れ図を図 4 に示す。システムの入 カデータは, 環境データ, 日負荷パターン, 太陽電池アレ イ容量，インバー夕効率などであり，次の三つのモードを 判別しながら 8,760 時間について 1 時間ごとに繰り返し計 算して太陽電池アレイ面積, 水素貯蔵量, 年間のエネルギ 一バランスなどを求めている。

（1）直接供給モード 太陽電池アレイで発生した電 力はインバータを介して負荷に供給される。また，その際 の余剰電力は水素モジュールへ送られ，水素として変換さ れ貯蔵される。このモードでは, 水素モジュールからの電

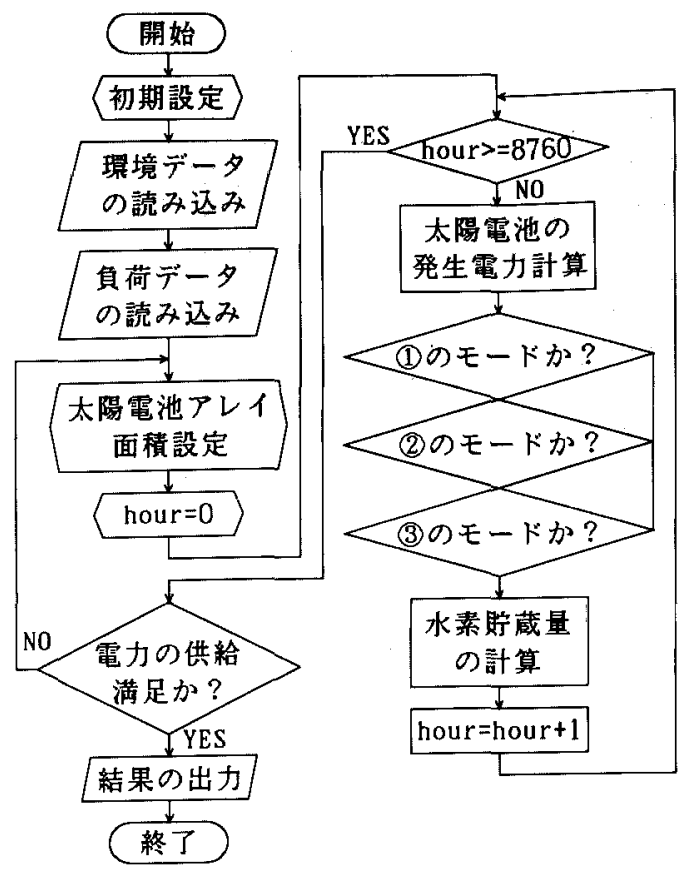

図 4 流れ図

Fig. 4, Flow chart.

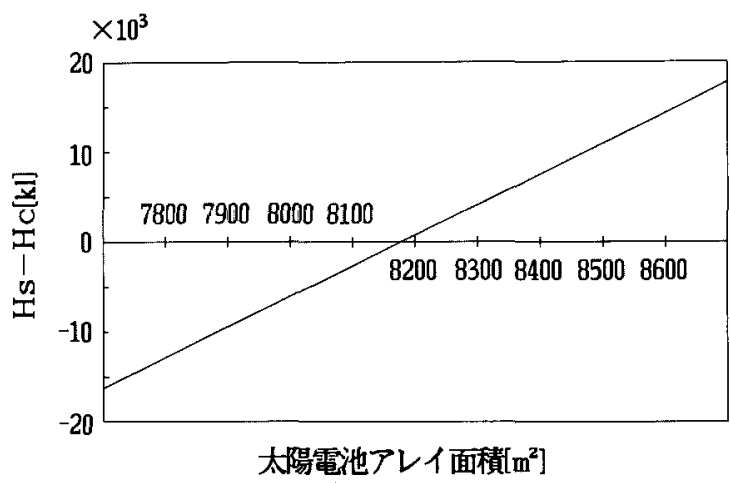

図 5 太陽電池アレイ面積と $\left(H_{s}-H_{c}\right)$ の関係 Fig. 5. Relationship between PV array area and $\left(H_{s}-H_{c}\right)$.

力供給はない。

（2）間接供給モード＼cjkstart貯蔵した水素を，燃料電池で 電力変換して負荷に電力を供給する。このモードでは，水 素モジュールへの電力供給はない。

（3）併用供給モード明け方，夕方など太陽電池ア レイで発生した電力が十分でないとき，(1)，(2)両モー ドを併用して負荷に電力を供給する。このモードでは，水 素モジュールへの電力供給はない。

\section{5. 結果と考察}

図 5 は, 負荷形状率 $31 \%$ 負荷パターンに対する太陽 電池アレイ面積と，水素発生機によって製造された年間水 素量 $H_{s}$ と燃料電池に供給された年間水素量 $H_{c}$ との差の 関係である。横軸は太陽電池アレイ面積 $\left(\mathrm{m}^{2}\right)$ であり, 


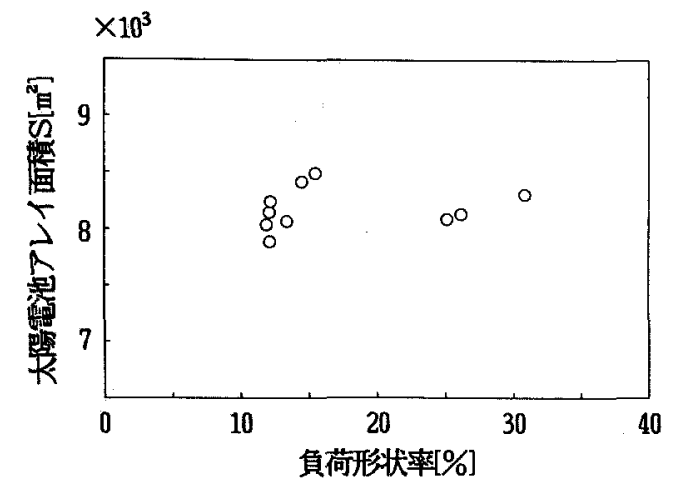

図 6 負荷形状率に詨する太陽電池アレイ 面積 $S$ の関係

Fig. 6. Relationship between electrical load form factor and $S$.

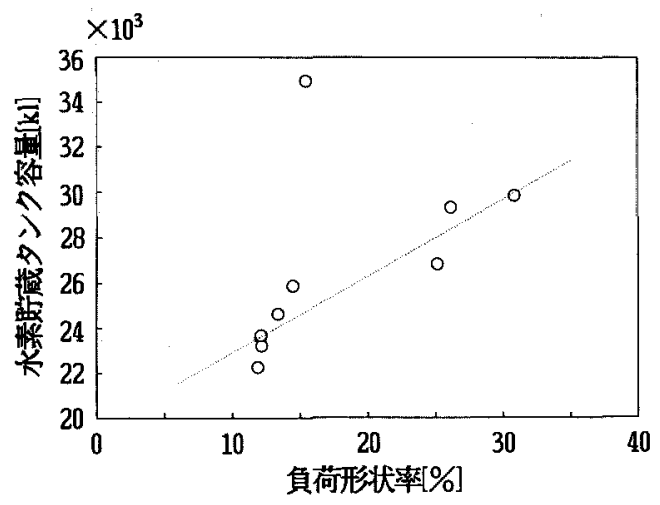

図 7 負荷形状率に対する水素貯蔵タンク容量の 関係

Fig. 7. Relationship between electrical load form factor and volume of storaged hydrogen tank.

縌軸は水素発生機によって製造された年間水素量 $H_{s}$ と燃 料電池に供給された年間水素量 $H_{c}$ との差 $(\mathrm{k} l)$ である。 いま, 年間の負荷電力を太陽電池アレイから直接供給する 電力と燃料電池から供給する電力でまかなうことにする。 このとき, 年間で製造した水素量をすべて燃料電池で電力 に変換するシステム容量, すなわち $H_{s}-H_{c}=0$ となるシス テム容量を最適容量のシステムと定義する。図より, 最適 なシステムの太陽電池アレイの面積は $8,170 \mathrm{~m}^{2}$ となった。

また，負荷パターンの負荷形状率に対する太陽電池アレ 亿面積, 水素貯蔵タンク容量の関係を求め, 図 6 , 図 7 に 示す。図 6 の太陽電池アレイ面積は, 負荷形状率の変化に 影響されず，ほほ一定 (約 $8,170 \mathrm{~m}^{2}$ ) となった。一方，図7 の水素貯蔵タンク容量は負荷形状率の変化に影響を受け る。例えば，負荷形状率が $10 \%$ から $30 \%$ に変化すると水素 貯蔵タンクの容量は $22,900 \mathrm{k} l$ から $29,700 \mathrm{k} l$ と 1.3 倍程度 増加する。なお，図 7 の負荷形状率が約 $16 \%$ で, 水素貯蔵 タンク容量が大きな値となっているが，これは冬期夜間の 負荷が他の季節の負荷に比べて著しく大きいことによる。

図 8 に本システムの1日の稼働状況を示す。図 8 (a)は 快晴日（9月13日）の稼㗢状況で，6時から16時にかけ て(1)のモードで稼働し，0 時から 5 時，19時以降は

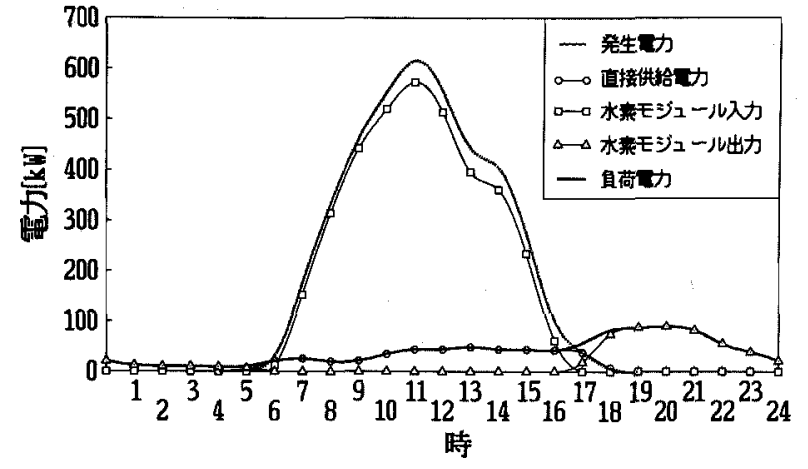

（a） 快晴日（9月13日）

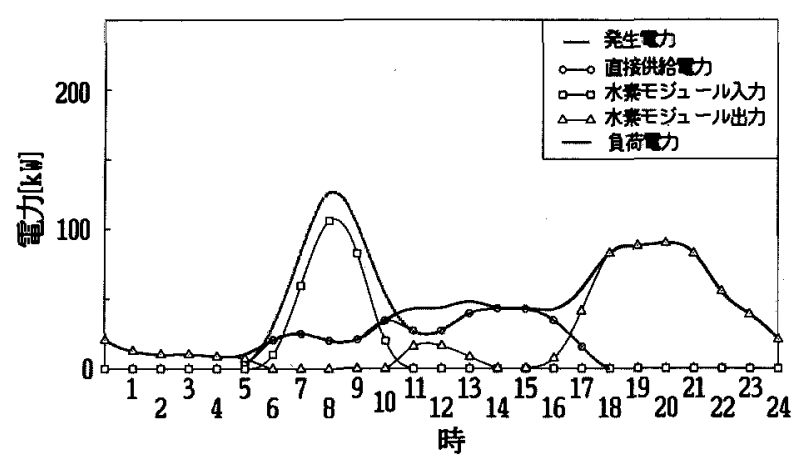

(b) 震天日（9月 8 日）

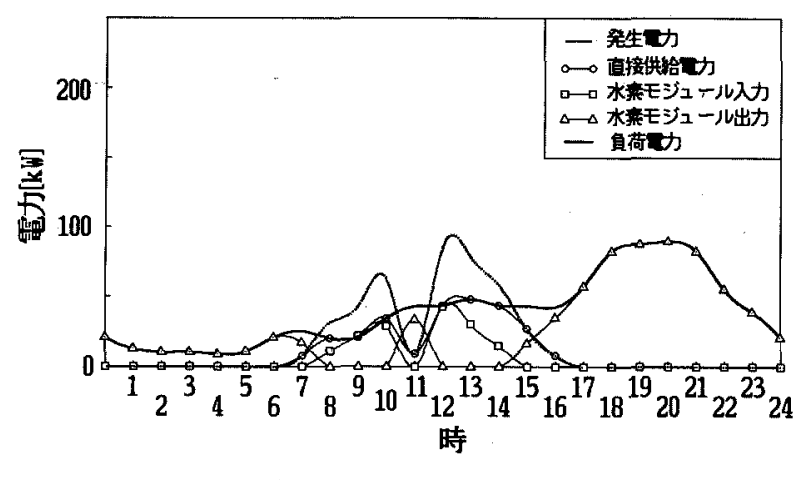

(c) 雨天日 (9 月 10 日)

図 8 1 日の稼働状況

Fig. 8. Characteristics of operation in a day.

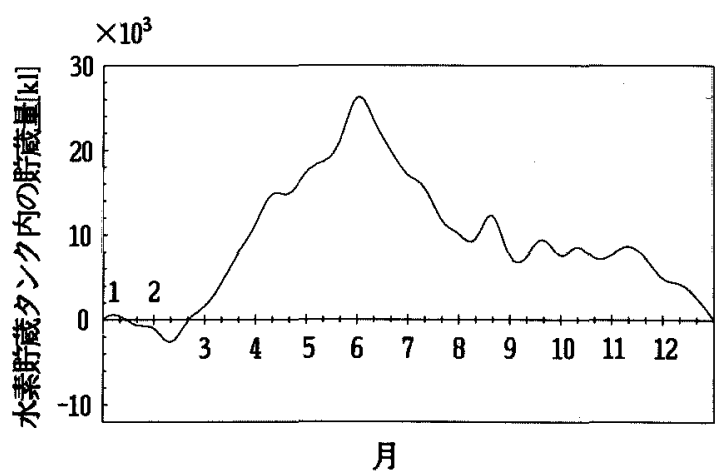

図 9 水素貯蔵タンク内の貯蔵量推移 Fig. 9. Change of storage in volume of hydrogen tank. 


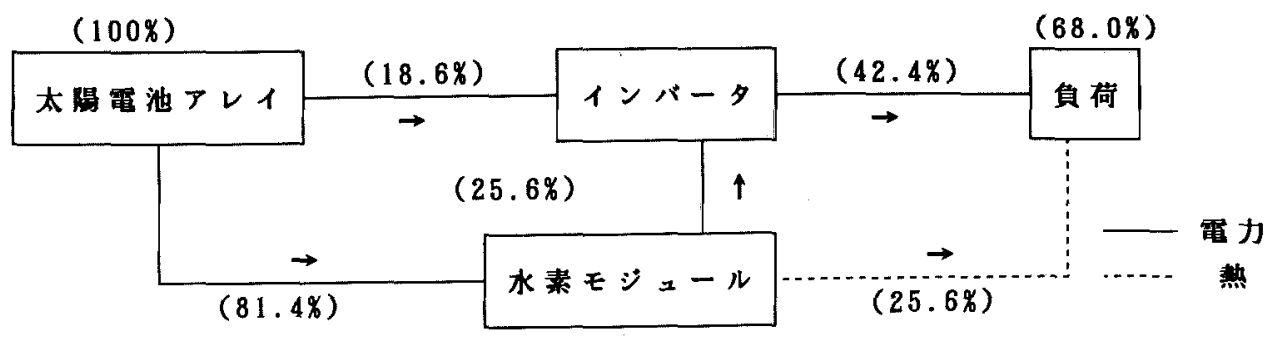

図 10 年間のエネルギーバランス

Fig. 10. Annual balance of energy.

(2)のモードで稼働する。また， 5 時から 6 時，16 時か ら19 時にかけて(3)のモードで稼働する。(b)，(c)図 は，それぞれ曇天日（9月 8 日), 雨天日（9月10日）の 稼働状況で，(a )図と同梯に稼働していることがわかる。

図 9 に水素貯蔵タンク内の年間貯蔵量推移を示す。太陽 電池アレイの面積は $8,170 \mathrm{~m}^{2}$ で, 負荷パターンの負荷形 状率は $31 \%$ あ゙る。同図より水素貯蔵タンクは，1月 1 日 0 時で完全に空で 2 月中旬に $2,600 \mathrm{k} l$ 不足となり, 3 月〜 5 月にかけて貯蔵量丳増加し 6 月上旬に最大值 26,300 $\mathrm{k} l$ となる。それ以降，12月まで減少し 12 月 31 日 24 時 に再び空になる。負荷に電力を安定的に供給するために は，2 月中旬に貯蔵量が不足する分 $(2,600 \mathrm{k} l)$ をあらか じめ充てんさせて扔く必要がある。従って，貯蔵タンクの 容量的約 $29,000 \mathrm{k} l$ となる。

本論文で検討した太陽光発電・燃料電池ハイブリッドシ ステムは完全自立形の独立システムであり，類似システム としては，蓄電池を有する太陽光発電システムがある。こ のシステムでは, 蓄電池群の充・放電効率, 自己放電率, 日射強度の変化による太陽電池アレイの出力電圧と蓄電池 群の充電電圧との整合性などを考慮する必要があり, 設計 条件によっては必ずしも太陽エネルギーを有効に利用して いるとはいい難いシステムとなる(11)。このような観点か ら，本システムと蓄電池を有する太陽光発電システムの年 間のエネルギーバランスを検討した。

図 10 は本システムの年間のエネルギーバランスである。 太陽電池アレイの年間の出力量を $100 \%$ とすると, インバ 一夕を介して直接負荷に供給される量は $17.9 \%$, 水素モ ジュールに供給される量は $81.4 \%$ となる。本システムで 想定した燃料電池はリン酸型燃料電池であり, 反応時の 170 $180^{\circ} \mathrm{C}$ 程度の反応熱を $40.0 \%$ 有効利用することによ り，結果として $68.0 \%$ のネルギーが利用できる。一方， 蓄電池群を有する太陽光発電システムについては, 蓄電池 群の充・放電効率を $70.0 \%$, 蓄電池群の自己放電率を 1 日 当たり充電量の $0.5 \%$, 年間の太陽電池アレイの出力電圧 と蓄電池群の充電電圧とのミスマッチングによる損失を $5.0 \%$, あるいは, 蓄電池群の DC-DCコンバータの変換 効率を $96.0 \%$ として, 年間のエネルギーバランスを計算 した。その結果, 両者ともに太陽電池アレイの年間出力量 のほ果 $62.4 \%$ のネルギーを有効に利用できることがわ
かった。

ここで, 燃料電池の発電後の $170 \sim 180^{\circ} \mathrm{C}$ 熱エネルギ 一を損失なく有効利用できるとした。また, 燃料電池の起 動，停止は瞬時に行われると仮定して計算した。これらに ついては今後実状にあった検討が必要であるが，運用によ っては太陽光発電・燃料電池ハイブリッドシステムは, 蓄 電池群を有する太陽光発電システムより太陽光エネルギー を有効に利用しうることがわかった。

両者の比較にあたってはエネルギー利用率のみならず, 経済性，信頼性などを加味して総合的に評価する必要があ る。しかし，著者らが提案しているシステムは，研究開発 途上にあり，今後，特性が大きく改善されることが期待さ れる。従って，ここではエネルギー利用率についてのみ, それも現状で考えられる妥当な数值を用いて比較したにと どめた。

\section{6. おわりに}

著者らが提案した太陽光発電・燃料電池ハイブリッドシ ステムによる個人住宅用負荷（個人住宅 100 軒相当, 年間 負荷電力量 $400 \mathrm{MWh}$, 平均電力 $45.7 \mathrm{~kW})$ への電力供給 の可能性について，シミュレーションにより検討した。そ の結果, 次のことが明らかになった。

（1）負荷に安定して電力を供給することができる。

（2）年間の負荷電力量をすべて供給する本システムの 太陽電池アレイ面積は, 約 $8,170 \mathrm{~m}^{2}$ で負荷形状率の違い に活とんど影響されない。

（3）年間の水素貯蔵量活春期の 3 月から 5 月にかけて 増加し， 6 月上旬にその量が最大となり, 夏期から秋期に かけて貯蔵した水素を使用しながら電力を供給する。

（4）年間の負荷電力量をすべて供給するには水素を貯 蔵する必要があり, 負荷形状率は水素貯蔵量に影響する。 例えば，負荷形状率が $12 \%$ のき水素貯蔵量は $2.4 \times 10^{4}$ $\mathrm{k} l$ であり，また， $31 \%$ とき $3.0 \times 10^{4} \mathrm{k} l$ となった。

（5）太陽電池アレイの出力量を基準にした電気エネル ギーの利用率は $42.4 \%$ となった。た, 燃料電池システ 么の発電に伴う熱エネルギーをも併せて利用すればこの值 は $68.0 \%$ に上昇する。この值は蓄電池を有する太陽光発 電システムの $62.4 \%$ よ良好で，運用によっては本シス テムは太陽エネルギーを有効に利用できる。 
本システムは, 本論文で検討した離島などの家庭用電源 はもとより, 比較的負荷電力量の大きいホテル, 集合住 宅，製造業などの産業分野への適用が期待できる。

(平成 5 年 5 月 24 日受付)

\section{文献}

（1）原口隆文・野中 宏・相羽光大・谷 辰夫：「太陽光発電・燃料 電池ハイブリッドシステムの稼働シミュレーション」, 太陽エネ ルギー, 18, No. 5, 33 (平 4-11)

(2) 例えば, M. Al-Garni : "SOLAR HYDROGEN IN SAUDI ARABIA : A LONG-TERM OUTLOOK", Proc. 1991 ISES Cong. Denver Colorado, p. 735 (1991)

（3）本間琢也：「WE-NET 構想（総合プロジェクトの国際展開一 エネルギー・環境問題の同時解決一)」, 第 12 回工業技術院筑波 総合シンポジウム, p. 75 (平 5)

（4）谷 辰夫・横内博之：「系統連系形太陽光発電システムの最適設 計」, 電学論 D, 111, 475 (平 3-6)

（5）郡 啓太・谷 辰夫：「系統連系形太陽光発電システムの最適設 計」, 第 9 回エネルギーシステム・経済コンファレンス，2-3(平 5)

（6）小林 誠・谷 辰夫：「環境因子の変化に対する太陽電池モジュ ールの出力特性」, 平 3 日本太陽エネルギー学会・風力エネルギ 一協会・合同研究発表会, No. 15,85

（7）星野・工藤・木村・塩谷：「太陽光発電システムに㧧けるDC-DC コンバータおよびインバータに関する研究」, 電気学会半導体電 力変換研資, SPC-88-36, 53 (昭 63)

(8) P. D. Metz \& M. Piraino: "PHOTOVOLTAIC-POWERED SOLID POLYMER ELECTROLYTE (SPE) ELECTROLYZER SYSTEM EVALUATION", FINAL REPORT. US DOE REP (BNL-51940), p. 55 (1985)

（9）新エネルギー総合開発機構（委託先 財団法人 電力中央研究 所）：昭和 60 年度調查報告書 23 「太陽光発電の価值評価に関す る調查研究 (II) 」, p. 66 (昭 61-3)

（10）田辺・安田・横山：「 $\mathrm{CO}_{2}$ 排出制御下における電源ベストミック スの分析」, 電気学会新省エネルギー研資, ESC-92-43 (平 4)

(11) 谷 辰夫：「太陽光発電システムの設計に関する一考察」, 電学 論 $\mathrm{D}, 108,41$ (昭 63-2)

関 口 直 佁

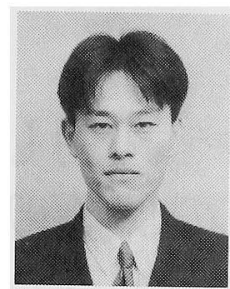

（非会員） 1969 年 8 月 7 日生。 1993 年 3 月東京 理科大学工学部第 2 部電気工学科卒業。同年 4 月同大学大学院工学研究科電気工学専攻修士課 程入学。現在, 同課程に枋いて太陽エネルギー 利用技術に関する研究に従事。日本太陽エネル ギー学会学生員。

藤 木 靖 之（非会員）1969年 6 月 19 日生。1993 年 3 月東

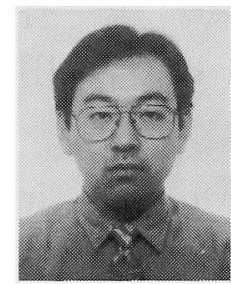
京理科大学工学部第 2 部電気工学科卒業。同年 4 月ソニー・テクトロニクス(株)入社。現在，テ レビジョン・システム機器事業部所属。

谷

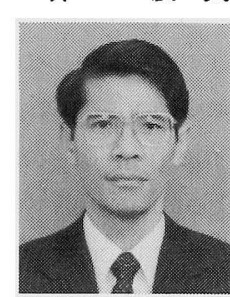

（正員） 1940 年生。1966 年 3 月名古屋工業大学 大学院工学研究科修士課程修了。同年 4 月通産 省電気試験所(現，電子技術総合研究所)入所。 同エネルギー部太陽エネルギー研究室長を経て, 1988 年 4 月東京理科大学工学部教授, 現在に至 る。工学博士。エネルギー変換工学担当。 